\title{
After fifty years, a mixed verdict
}

"THE general public has not been unaware of, or ungrateful for, the contributions made by science to the task of defeating the enemy," wrote Nature the week after the cessation of hostilities with Germany in May 1945 (155, 553; 1945). "Indeed, there have been times when it has been necessary to check public enthusiasm and to remind people at large that science alone could not achieve [this result]."

Nevertheless, scientists were quick to exploit this outburst of enthusiasm which, significantly, existed well before the public had become aware of the contribution of science to the development of the atomic bomb. Once the war had ended, plans were rapidly laid for schemes to ensure that both basic and applied science played as vital a part in post-war reconstruction as it had in war-time. These plans found their most articulate expression in Science - The Endless Frontier, an evocative and influential report presented by Vannevar Bush, director of the Office of Scientific Research and Development, to President Harry Truman.

But the United States was not alone. In France, substantial state support for basic research was channelled through the Centre Nationale de la Recherche Scientifique. In Germany, thanks partly to the support of British colleagues, nuclear physicists who had opposed Hitler were able to oversee the foundations of the highly successful system of Max Planck Institutes.

Fifty years on, however, as this brief survey contrasting the worlds of 1945 and 1995 demonstrates, the impact of the powerful post-war legacy on science remains mixed. On the one hand, science has kept much of its social promise, providing the advances in fields such as materials research, information technology and biotechnology that form the backbone of modern economies.

In turn, governments have kept much of their promise to basic science. Until recently, academic research has grown steadily, while decisions on the distribution of these funds has remained largely in the hands of the scientific community.

But there are signs that the post-war paradigm is breaking up. The vital role of science in the economy remains accepted, but further growth in basic research is no longer guaranteed by governments, which are increasingly keen to see 'strategic priorities' imposed on the science base.

At the same time, in virtually all industrialized nations, many of the massive statefunded laboratories set up in the 1940s and 1950s to pursue social goals - in particular, the military and civilian applications of nuclear power - have become political albatrosses, deprived of their original political and technological goals, but lacking the flexibility to respond speedily to the demands of the modern industrial world.

Nor is the prestige of scientists as high as it was in 1945. Indeed, perhaps May of that year saw its zenith; as Sir Michael Atiyah pointed out in his recent valedictory address as president of the Royal Society (see Nature 378, 525; 1995), the image of the benign, truth-seeking scientist suffered a damaging blow with the advent of nuclear weapons from which it has never fully recovered.

Few of the scientists who were engaged in the post-war reconstruction and are still alive today can be disappointed at the results of their efforts $\mathbf{5 0}$ years later. But many will no doubt still harbour regrets, some at the continuing failure of science to meet many of the world's needs, others at continued disputes about the future of nuclear weapons - the genie that is still not yet firmly back in the bottle - and new threats created by mankind's activities, such as those of global warming.

In the light of subsequent experience, many of the post-war ambitions turn out to have been highly optimistic. But without such optimism, the challenges of the future would remain daunting indeed.

\section{US science funding finally hits the frontier}

Washington. Science is "like a fish swimming in water," says Norman Metzger, head of physical sciences at the National Research Council (NRC), the research arm of the US National Academy of Sciences in Washington DC. "It doesn't realize it's in water until you take the water away."

Since the end of the Second World War, the 'water' for US science has been the steady growth in funding - most of it from the federal government - which has supported new individuals and areas of research without directly threatening those already well established. But the tap has now been turned off; and 1995 was the year when the science community began fully to recognize that fact.

It is often said that Vannevar Bush, director of the Office of Scientific Research and Development set the stream in motion with his report, Science - The Endless Frontier, commissioned by President Franklin Roosevelt as a blueprint for the country's post-war scientific effort, and delivered to his successor, President Harry Truman, in July 1945.

The seminal report was confident in its proposals. A new National Research Foundation (NRF) should be set up, it said, with a budget growing rapidly to $\$ 120$ million a year. It would, among other ambitious goals, provide 28,000 scholarships to boost a scientific workforce depleted by the demands of wartime military service.

Yet it is often forgotten that the central point of Science - The Endless Frontier was never implemented. The NRF - a true Department of Science proposal if ever there was one, and not entirely dissimilar to ideas currently being promoted by Republicans in Congress - took five years to get off the ground, in cur- Bush: set framework tailed form, as the for US science in 1945. National Science Foundation (NSF). By that time the key areas of health and military research, which Bush expected to account for almost half of its budget, had been taken on by the new National Institutes of Health (NIH) and the Pentagon respectively.

Another myth about Bush is that his proposals were accepted without political rancour. In fact, his report was a clarion call for the support of science on scientists' own terms, and was accepted in the face of opposition from Senator Harley Kilgore of West Virginia and others who argued that science should be directed to meet social and economic goals. That debate has never been fully resolved, and continues to this day: witness the recent efforts of Senator Barbara Mikulski (Democrat, Maryland) to foist "strategic goals" on the NSF.

Yet it was not Bush's vision of science for its own sake, still less his failed proposal for an NRF, that drove the post-war explosion in federal support for research. Rather, it was the rapid expansion of mission-oriented research through government agencies. Sometimes the impetus came from the executive branch, such as the creation of the National Aeronautics and Space Administration (NASA), in October of 1958; and sometimes from Congress, as with the buildup of the NIH in the 1980s and early 1990s.

Money was available to satisfy this political pressure, as the annual budget spent at the discretion of the US Congress mushroomed with the US economy. Recession in the 1970 s temporarily bucked the trend. But the overall trajectory was clear (see graph on next page). "Our central motif was: don't have a science policy," says Metzger. "One could do that in a time of fairly steady 